\title{
Short-term predation responses of adult bay anchovies Anchoa mitchilli to estuarine zooplankton availability
}

\author{
William S. Johnson' ${ }^{1}$, Dennis M. Allen ${ }^{2}$, M. Virginia Ogburn², Stephen E. Stancyk ${ }^{2}$ \\ ${ }^{1}$ Department of Biology, Goucher College, Towson, Maryland 21204, USA \\ ${ }^{2}$ Belle W. Baruch Institute for Marine Biology and Coastal Research, University of South Carolina, Georgetown, \\ South Carolina 29442, USA
}

\begin{abstract}
Feeding activity and prey selection of adult bay anchovies Anchoa mitchilli in the highsalinity North Inlet Estuary, South Carolina (USA), were examined during 2 summer days and nights in 1985. Stomach contents were compared to 2 size fractions of zooplankton (153 and $365 \mu \mathrm{m}$ mesh) collected at the same time (every $2 \mathrm{~h}$ ) and place (near the bottom) in a tidal creek. Adult bay anchovies (40 to $60 \mathrm{~mm}$ ) consumed a wide variety of zooplankton, but selected items according to prey size, density, and type. Most prey items were between about 0.4 and $3.25 \mathrm{~mm}$ in length, although some copepods (less than $0.3 \mathrm{~mm}$ ) and decapod shrimps (up to about $12 \mathrm{~mm}$ ) were eaten. Among the available potential prey taxa, crab (primarily $U_{C a}$ ) megalopae were by far the most important. Uca megalopae comprised almost $60 \%$ of the diet based on numbers and volume and were favored even when their densities were much lower than other similar sized animals. First stage pinnotherid crabs and hydromedusae were completely avoided. There were distinct tidal and diel rhythms in feeding patterns and prey selection. Generally, large prey (e.g. Uca megalopae, shrimp zoeae, amphipods) dominated the diet around high tide especially at night, and small items (e.g. copepods, Uca zoeae, bamacle cyprids) were most important around daytime low tide when larger prey items were less abundant in the water column. Rapid changes in feeding were observed when preferred prey became available, especially around dusk. Adult anchovies fed throughout the night and immediately responded to the sudden availability of crustacean larvae originating from nocturnal hatching events. All evidence suggests that adult anchovies are selective particle feeders which probably rely on more than vision alone to determine prey suitability. As a widely distributed and abundant planktivore, $A$. mitchilli represents a major link in estuarine food webs and probably plays a significant role both in the survival patterns of benthic invertebrate larvae and in the dynamics of estuarine zooplankton communities.
\end{abstract}

\section{INTRODUCTION}

The relationship between planktivores and their prey has received a great deal of attention in recent years. Prey selection at different levels of prey density and under different environmental conditions is an important determinant of predator and prey dynamics (Murdock 1969) and thus may play a major role in structuring water column communities (Brooks \& Dodson 1965, Lynch 1979, Kitchell \& Carpenter 1987). Most research in this area has been conducted in small freshwater systems where it has been repeatedly demonstrated

- Contribution no. 807 to the Baruch Institute for Marine Biology and Coastal Research, University of South Carolina that both fish and invertebrate planktivores can have a marked impact on zooplankton prey communities (O'Brien 1979, Zaret 1980, Lazzaro 1987). In temperate estuaries, large variations in physical, chemical, and biological characteristics of the water column occur on the scale of seasons and years (Wolfe \& Kjerfve 1986). Superimposed on these pattens are diurnal, diel, and tidal fluctuations in temperature, salinity, turbidity and other physical parameters. Such short-term fluctuations are known to influence the abundance and composition of plankton (Lee \& McAlice 1979, Christy \& Stancyk 1982, de Lafontaine et al. 1984, Stubblefield et al. 1984); however, little is known about the responses of planktivorous fishes to rapid changes in the physical environment or to changes in prey availability. 
In general, estuarine food webs are more complex than those in fresh water, but their trophic structures are similar. Relatively small fishes represent an important link between primary consumers and what is often the highest level of the food chain. In temperate western Atlantic estuaries, one planktivore, the bay anchovy Anchoa mitchilli, is especially abundant (Hildebrand \& Shroeder 1928, Gunter 1945, Allen et al. 1978, Leak \& Houde 1987). In a 4 yr survey of fishes in North Inlet Estuary, South Carolina (USA), A. mitchilli was by far the most abundant fish in the estuarine waterways, particularly in spring and summer (Ogburn et al. 1988). Rapidly changing conditions in a tidally dominated estuary offer an excellent opportunity to study short-term changes in dietary shifts and the nature of prey selection. This study examines hourly changes in the feeding patterns of adult $A$. mitchilli in relation to fluctuations in physical conditions and potential prey availability during a $40 \mathrm{~h}$ summer period. Due to the singular abundance and turnover rate of this widely distributed planktivore, understanding its feeding in nature should increase our knowledge of energy transfer within estuarine food webs.

\section{METHODS}

Study area. The North Inlet Estuary is a $28 \mathrm{~km}^{2}$ Spartina alterniflora dominated ecosystem located in the north-central portion of the South Carolina coast (Fig, 1). Semidiurnal tides maintain high salinities $\{30$ to $35 \mathrm{ppt}$ ) in the well-mixed major waterways for most of the year. Tidal range is from 1.1 to $2.5 \mathrm{~m}$ (neap and spring tides respectively) and mean tidal range is 1.4 m. Approximately $55 \%$ of the water within the estuary at high tide is flushed to the ocean on an ebbing tide (Dame et al. 1986). Typical peak tidal current velocities are about $1.3 \mathrm{~m} \mathrm{~s}^{-1}$ in a major creek, but can reach more than $2 \mathrm{~m} \mathrm{~s}^{-1}$ on spring tides (Kjerfve 1978, Kjerfve et al. 1982).

All collections were made at Stn BB in Town Creek ca $2.0 \mathrm{~km}$ west of the mouth of North Inlet (Fig. 1). This site has a depth of about $3 \mathrm{~m}$ at low tide and is typical of major tidal creek habitats in the region. The bottom is composed of a firm mixture of mud and shell which supports growths of sponges, hydroids, sea whips, bryozoans, oysters, and other fouling organisms. In 1980 , this station was designated as a permanent sampling location for the Longterm Ecological Research Project funded by the National Science Foundation. Four yr of seine and trawl data and 10 yr of 153 and $365 \mu \mathrm{m}$ zooplankton data have been collected at this site

Field sampling. Fishes, macrozooplankton (>365 $\mu \mathrm{m}$ ) and zooplankton (> $153 \mu \mathrm{m}$ ) were collected every $2 \mathrm{~h}$ for $40 \mathrm{~h}$ beginning at 07:00 h on 4 June 1985.

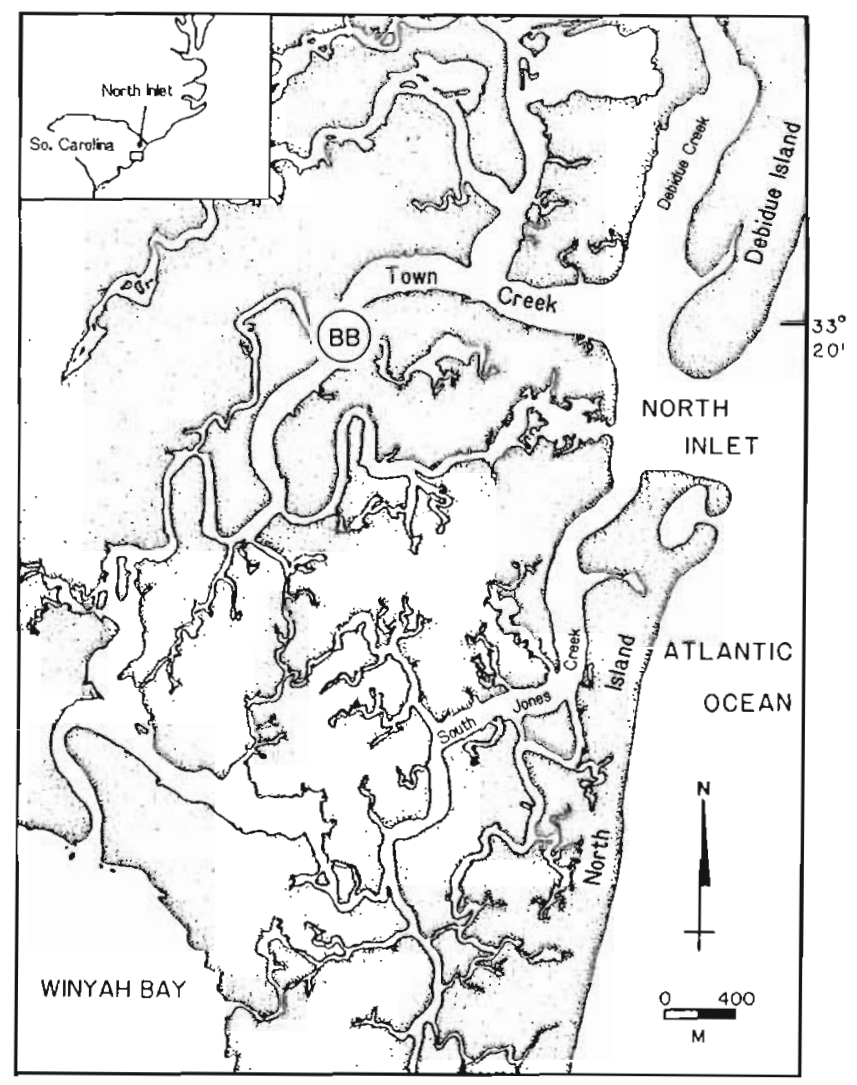

Fig. 1. Location of $40 \mathrm{~h}$ sampling site (labelled BB) in Town Creek, North Inlet Estuary, South Carolina, USA

Additional information on fishes and macrozooplankton was collected every hour. Since adult bay anchovies were most abundant near the bottom, collections were made using a $4.88 \mathrm{~m}$ wide otter trawl (with a $1.27 \mathrm{~cm}$ stretch mesh codend) that sampled the bottom 1 to $1.5 \mathrm{~m}$ of the water column. Adult anchovies were isolated from the catch and their abdominal cavities injected immediately with preservative $15 \%$ buffered formalin, $4.5 \%$ propylene glycol, $0.5 \%$ propylene phenoxetol; Steedman 1976) before being stored in $10 \%$ buffered formalin. Zooplankton within $50 \mathrm{~cm}$ of the bottom were collected bihourly using a $2 \mathrm{hp}$ centrifugal pump from a boat anchored adjacent to the towpath. Two sequential pump samples of $1 \mathrm{~m}^{3}$ of water were filtered through a $153 \mu \mathrm{m}$ mesh net. Comparisons of densities of zooplankton in pump samples with those in 2 simultaneous bottom $153 \mu \mathrm{m}$ nets collections indicated that for all common categories, pumps collected the same or greater numbers of individuals; hence, for these small organisms, pump avoidance was not a problem. Macrozooplankton within $30 \mathrm{~cm}$ of the bottom were collected hourly using paired $365 \mathrm{\mu m}$ mesh sleds towed along the $100 \mathrm{~m}$ towpath in the direction of tidal flow. A General Oceanics mechanical flowmeter (model 2030R) was used to estimate the 
volume of water filtered on each tow (30 to $40 \mathrm{~m}^{3}$ ). All zooplankton samples were preserved immediately with buffered formalin stained with Rose Bengal to make a final concentration of 5 to $10 \%$. Water temperature, salinity, light, and current velocity were recorded hourly at $50 \mathrm{~cm}$ depth intervals. Salinity was measured using a Beckman RS-5 salinometer, light with a LI-COR \#L1-185B light meter, and water velocity with a Marsh-McBirney (Model \#210D) portable water current meter

Laboratory analysis. Zooplankton from pump collections were subsampled using a $2 \mathrm{ml}$ Stempel pipet. All organisms were enumerated and identified using an inverted microscope. Copepods were identified to genus or species and developmental stage (adult copepodid, nauplius). Other zooplankton (mostly small invertebrate larvae) were identified to the lowest possible taxon. Macrozooplankton samples with a settled volume of $100 \mathrm{ml}$ or more were divided with a cylindrical splitting apparatus to obtain a subsample which was never less than $6.25 \%$ of the original volume. All organisms were identified to the lowest possible taxonomic level and enumerated at 60 to $120 \times$ under a dissecting microscope. For each taxon which occurred in both zooplankton and macrozooplankton collections, the number from the device (pump or sled) which collected the most animals was used in analyses.

Bay anchovies from each hourly collection were measured and separated into $10 \mathrm{~mm}$ size classes. Within each size class of each hourly sample, 5 to 15 individuals were dissected. The stomachs (anterior to the intestine) were removed, and the contents were identified to lowest possible taxon and enumerated. The volume of each food catergory and the proportion of the total volume it comprised was recorded. A total of 630 fish stomachs were examined for diet contents. From these fish, stomachs which contained fewer than 10 items, had contents too digested to be identified, or had less than $30 \%$ fullness by volume were excluded from all analyses except for the estimation of feeding intensity. A total of 418 fish were used in all other analyses. Fish of 40 to $59 \mathrm{~mm}$ standard length (SL) dominated the catch. Since comparisons showed no significant difference between the stomach contents (prey number and volume) of the 40 to $49 \mathrm{~mm} \mathrm{SL}$ and 50 to $59 \mathrm{~mm}$ SL size classes, the results for all adult fish ( 40 to $59 \mathrm{~mm} \mathrm{SL}$ ) were combined in the analyses.

Analysis of variance was performed on data which were transformed to $\log _{10}(x+1)$ to nomalize the distribution and decorrelate means and variances. Statistical analyses were based on the General Linear model ANOVA procedures of SAS (SAS Institute 1982). Comparisons between high and low tide means were based on samples collected within $2 \mathrm{~h}$ of predicted high or low tide for North Inlet Estuary. Comparisons of day and night means were based on groups of samples collected during the following intervals: day $=06: 30$ to $19: 29 \mathrm{~h}$, night $=19: 30$ to $06: 29 \mathrm{~h}$. The factors of photoperiod and tide in the ANOVA were treated as fixed effects in the model.

An index of feeding electivity, L (Gabriel 1979), was used to provide a measure of relative selectivity. $\mathrm{L}$ is the natural log of the odds ratio (Fleiss 1973; also identical to the 'forage ratio', Jacobs 1974) calculated as $\ln \left(\mathrm{P}_{1} \mathrm{Q}_{2} / \mathrm{P}_{2} \mathrm{Q}_{1}\right)$ where $\mathrm{P}_{1}$ is the percent in the diet, $\mathrm{Q}_{1}$ is the percent of all other prey eaten (or $100-\mathrm{P} 1$ ), $\mathrm{P}_{2}$ is the percent of the taxon in the plankton, $Q_{2}$ is the percent of all other potential prey $\left(100-Q_{1}\right)$. An $L$ of zero indicates no selection. Values greater than zero indicate positive selection and those less than zero suggest negative selection. This index was used because it allows the comparison of wide ranges in selectivity (Jumars et al. 1982). Electivity values were calculated with stomach content data from fishes collected within 40 min following plankton collection.

\section{RESULTS}

Over the course of the $40 \mathrm{~h}$ study, bottom water temperatures ranged from $26^{\circ} \mathrm{C}$ during high tides to $31^{\circ} \mathrm{C}$ during daytime low tides. Minimum and maximum temperatures on the second day were about $1^{\circ} \mathrm{C}$ cooler than the first day. Salinity values remained about 35 ppt, except when the salinity fell to $31 \mathrm{ppt} 2 \mathrm{~h}$ after daytime high tide on both days. A minimum salinity of 31 ppt was also observed just after low tide on the second day. Current velocities $50 \mathrm{~cm}$ above the bottom ranged from 0.05 to $0.69 \mathrm{~m} \mathrm{~s}^{-1}$. Maximum current velocities were recorded $2 \mathrm{~h}$ into the ebbing tide. Light intensities $50 \mathrm{~cm}$ above the bottom the first day ranged from $34.0 \mu \mathrm{E} \mathrm{s}^{-1} \mathrm{~m}^{-2}$ at dawn and dusk to $1100 \mu \mathrm{E} \mathrm{s}^{-1} \mathrm{~m}^{-2}$ around noon. Light intensities the second day were generally greater and reached a peak level of $1950 \mu \mathrm{E} \mathrm{s}^{-1} \mathrm{~m}^{-2}$ an hour before noon.

\section{Overall feeding pattern}

Over 16000 items representing 60 taxa were identified from the 418 adult bay anchovy stomachs. These taxa were grouped into 9 major diet categories (Table 1 ). Both in terms of numbers and frequency of occurrence, crab megalopae dominated the diet. Crab zoeae and copepods (virtually all adults) were the next most important diet categories, and each prey type occurred in at least half of the stomachs examined. Since more than $99 \%$ of all decapod crab megalopae and most zoeae were Uca spp., subsequent references to these categories will be Uca megalopae and Uca zoeae, 
Table 1 Anchoa mitchilli anchovies. Total number and relative frequency of prey items which occurred within the stomachs of the 418 anchovies collected during the $40 \mathrm{~h}$ study. Major categories are listed in order of abundance and are subdivided into constituent taxa

\begin{tabular}{|c|c|c|}
\hline Diet category & Number & Occurrence $(\%)$ \\
\hline Decapod crab megalopae & 9029 & 71.3 \\
\hline$U_{C a}$ spp. & 8978 & 68.4 \\
\hline Panopeus spp. & 26 & 4.1 \\
\hline Callinectes spp. & 13 & 2.3 \\
\hline Neopanopeus spp. & 5 & 1.2 \\
\hline Unidentified xanthids & 7 & 1.7 \\
\hline Crab zoeae & 3870 & 49.5 \\
\hline Uca spp. \& Sesarma spp. & 2955 & 27.0 \\
\hline Callinectes spp. & 823 & 22.4 \\
\hline Panopeus sp. & 23 & 2.4 \\
\hline Unidentified xanthids & 69 & 8.6 \\
\hline Copepods & 1822 & 64.4 \\
\hline Acartia tonsa & 1138 & 46.9 \\
\hline Pseudodiaptomus coronatus & 271 & 27.3 \\
\hline Labidocera aestiva & 260 & 13.2 \\
\hline Parvocalanus crassirostris & 37 & 6.0 \\
\hline Euterpina acutifrons & 25 & 5.3 \\
\hline Centropages spp. & 14 & 1.9 \\
\hline Oithona colcarva & 11 & 1.6 \\
\hline Temora spp. & 4 & 0.7 \\
\hline Paracalanus spp. & 4 & 0.7 \\
\hline Corycaeus spp. & 3 & 0.5 \\
\hline Eurytemora affinis & 1 & 0.2 \\
\hline Unidentified copepods & 53 & 6.0 \\
\hline Copepod nauplii & 1 & 0.2 \\
\hline Decapod shrimps & 787 & 46.4 \\
\hline Callianassa spp. zoeae & 356 & 16.5 \\
\hline Palaemonetes spp. zoeae & 250 & 28.2 \\
\hline Alpheus spp. zoeae & 58 & 4.3 \\
\hline Upogebia affinis zoeae & 17 & 3.1 \\
\hline Lucifer faxoni juveniles & 10 & 2.2 \\
\hline Penaeus spp. postlarvae & 5 & 1.0 \\
\hline Acetes spp. juveniles & 1 & 0.2 \\
\hline Unidentified shrimp zoeae & 90 & 11.5 \\
\hline Bivalves & 324 & 30.1 \\
\hline Clams & 188 & 17.9 \\
\hline Mussels & 99 & 13.6 \\
\hline Oysters & 3 & 3.6 \\
\hline Unidentified bivalves & 34 & 0.5 \\
\hline Barnacle cyprids & 163 & 19.1 \\
\hline Amphipods & 141 & 17.5 \\
\hline Gammarids & 117 & 14.4 \\
\hline Caprellids & 24 & 4.5 \\
\hline Mysids & 49 & 7.2 \\
\hline Bowmaniella spp. & 27 & 2.9 \\
\hline Neomysis spp. & 10 & 2.3 \\
\hline Unidentified mysids & 12 & 2.2 \\
\hline Other & 127 & 21.5 \\
\hline Cumaceans & 32 & 3.6 \\
\hline Gastropods & 22 & 3.6 \\
\hline Polychaetes & 16 & 3.8 \\
\hline Ostracods & 14 & 2.4 \\
\hline Fish eggs & 14 & 1.2 \\
\hline Fish larvae & 5 & 0.7 \\
\hline Isopods & 3 & 0.4 \\
\hline Pinnotherids & 1 & 0.2 \\
\hline Miscellaneous (12 taxa) & 20 & 5.3 \\
\hline Total number of prey items & 16312 & \\
\hline
\end{tabular}

respectively. Of the 11 copepod species identified from the stomachs, only Acartia tonsa, Pseudodiaptomus coronatus, and Labidocera aestiva were eaten in large numbers. Zoeal and juvenile stages of decapod shrimp, most of which were Callianassa spp. or Palaemonetes spp., occurred in almost $50 \%$ of the fish. Gammarid amphipods and mysids were common in the stomachs and dominant in some samples. In contrast, barnacle cyprids and small shelled bivalves (post veligers) were never dominant in any sample or in individual fish, but were frequently observed in stomachs in small numbers throughout the $40 \mathrm{~h}$ period. None of the 20 'other' taxa was eaten in quantity at any time.

Fig. 2 compares the relative contribution of different prey to the diet both in terms of number and volume.

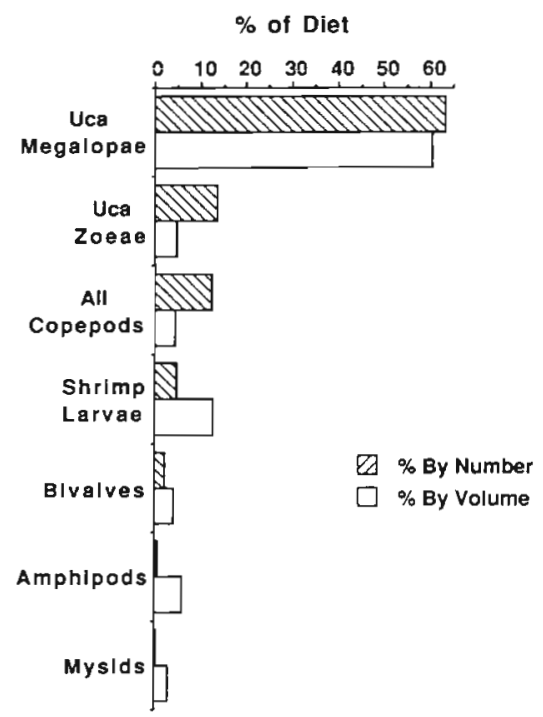

Fig. 2. Anchod mitchilli. Relative percent composition of overall diet by volume and by number. Each value represents average of all hourly sample means over the $40 \mathrm{~h}$ sampling period. Shrimp larvae include all the decapod shrimp taxa listed in Table 1

Since the prey differ greatly in size, the percent by number gives a better idea of the feeding pattern while the percent by volume provides an estimate of relative energetic contribution. Uca megalopae constituted about $60 \%$ of the diet both in terms of numbers and volume during the $40 \mathrm{~h}$ period. Uca zoeae and copepods were consumed in large numbers, but, due to their small size, contributed less to the overall volume. The larger prey items such as amphipods, mysids and decapod shrimp larvae were much more important in terms of volume despite their presence in relatively small numbers. Much of the bivalve biomass was shell, so their relative volume represents less caloric value than the other taxa. Barnacle cyprids contributed less than $5 \%$ to the overall diet in number and volume. 


\section{Comparison with availability}

A comparison of the number of zooplankton prey consumed to their densities in the water column (Table 2) shows that Anchoa mitchilli ate a relatively restricted subset of the potential prey available. Although copepod nauplii and copepodids $k$ ca $0.4 \mathrm{~mm}$ in length) and chaetognaths and larval fishes ( $>$ ca 3.25 $\mathrm{mm}$ in length) were abundant constituents of the zooplankton, almost none were found in adult bay anchovy stomachs. Most of the prey consumed were between 0.48 and $4.5 \mathrm{~mm}$ in length $(0.22$ and $1.17 \mathrm{~mm}$ in width); however, first stage crab pinnotherids and hydromedusae, which were within this size range, were not consumed despite their availability (Table 2). Within the range of preferred prey sizes, there was no consistent relationship between the number of prey available and their importance in the diet (Table 2).

For the major diet categories, ratios of numbers of prey eaten to densities in the water column varied considerably. A comparison of average feeding electivity values shows positive selection for most of the major diet categories, especially the larger taxa (Fig. 3). Values for Uca megalopae were several orders of magnitude greater than those for the next most selected items. Copepods were eaten in smaller numbers than expected from densities in the water column. A major exception was Labidocera aestiva, a large copepod whose selective index was among the highest for all diet categories. In contrast, the smaller Acartia tonsa and Pseudodiaptomus coronatus, although common prey, had negative selection coefficients. Among the smaller prey items, Uca zoeae and barnacle cyprids were selected for. Bivalve larvae were not consistently caught in sufficient numbers to calculate electivities.

\section{Changes over $40 \mathrm{~h}$}

Feeding occurred at all hours with marked shortterm variations in feeding intensity over the $40 \mathrm{~h}$ period (Fig. 4a); average values ranged from fewer than 4 items per stomach to over 125 . Significantly more feeding took place at high tide compared to low tide, and more feeding occurred during the day than at night (Table 3). While Anchoa mitchilli fed on both large and relatively small prey (Table 2), most prey items observed within each sample time belonged to one size class or the other. Smaller items dominated the diet during each low tide, but with the onset of the flooding tides large prey items became more abundant (Fig. 4b). During the day, this switch to larger prey was primarily

Table 2. Mean number of zooplankton and macrozooplankton collected and percentage of the total plankton and diet that each taxon comprised over the $40 \mathrm{~h}$ study. Capital letters indicate life stage of taxon used for comparisons (A, adults; C, copepodids; L, larvae). Taxa are ranked according to median length. Gear indicates whether the density data were obtained from $P$ (pump, 153 $\mu \mathrm{m}$ ) or $\mathrm{S}$ (sled, $365 \mu \mathrm{m}$ ) collections. Small prey are those taxa having a median length $<1 \mathrm{~mm}$; large prey taxa are $>1 \mathrm{~mm}$ in median length. Measurements were determined from a minimum of 10 individuals isolated from preserved plankton samples. Lengths and widths of organisms include major appendages and spines

\begin{tabular}{|c|c|c|c|c|c|c|}
\hline Diet item & $\begin{array}{c}\text { No. } \\
\text { collected }\end{array}$ & $\begin{array}{l}\text { Percent } \\
\text { plankton }\end{array}$ & $\begin{array}{c}\text { Percent } \\
\text { diet }\end{array}$ & Gear & $\begin{array}{l}\text { Length, mm } \\
\text { (Range) }\end{array}$ & $\begin{array}{l}\text { Width, mm } \\
\text { (Range) }\end{array}$ \\
\hline Bamacle cyprids & 240.0 & 1.77 & 0.99 & $\mathrm{P}$ & $0.48(0.44-0.48)$ & $0.22(0.20-0.22)$ \\
\hline Parvocalanus crassirostris (A) & 3742.7 & 27.71 & 0.22 & $\mathrm{P}$ & $0.50(0.48-0.53)$ & $0.16(0.14-0.18)$ \\
\hline Euterpina acutifrons (A) & 28.0 & 0.20 & 0.15 & $P$ & $0.59(0.46-0.64)$ & $0.19(0.15-0.21)$ \\
\hline Pinnotherids & 11.3 & 0.08 & 0 & $\mathrm{P}$ & $0.64(0.56-0.72)$ & $0.48(0.44-0.64)$ \\
\hline Crab zoeae & 1680.4 & 12.44 & 23.72 & $\mathrm{P}$ & $0.77(0.63-0.99)$ & $0.40(0.32-0.50)$ \\
\hline Fish eggs & 1.3 & $\cdot$ & 0.08 & $\mathrm{~S}$ & $0.80(0.72-0.84)$ & $0.80(0.72-0.84)$ \\
\hline Pseudodiaptomus coronatus $(\mathrm{A}+\mathrm{C})$ & 1251.0 & 9.26 & 1.66 & $P$ & $0.85(0.76-1.60)$ & $0.25(0.19-0.30)$ \\
\hline Bivalves & 1.2 & $\cdot$ & 1.98 & $\mathrm{~S}$ & $0.92(0.60-1.80)$ & $0.64(0.44-1.08)$ \\
\hline Acartia tonsa (A) & 6318.6 & 46.78 & 6.97 & $\mathrm{P}$ & $0.93(0.83-0.99)$ & $0.22(0.20-0.24)$ \\
\hline Crab megalopae & 15.3 & 0.11 & 55.35 & $\mathrm{~S}$ & $1.36(1.28-3.36)$ & $1.04(0.80-1.72)$ \\
\hline Upogebia affinis (L) & 1.9 & 0.01 & 0.10 & $\mathrm{~S}$ & $1.84(2.04-2.48)$ & $0.56(0.52-1.12)$ \\
\hline Labidocera aestiva (A) & 10.5 & 0.07 & 1.59 & $\mathrm{~S}$ & $2.72(2.44-6.96)$ & $0.60(0.56-0.76)$ \\
\hline Alpheus spp. (L) & 12.8 & 0.09 & 0.35 & $\mathrm{~S}$ & $2.83(2.75-7.25)$ & $0.52(0.44-1.00)$ \\
\hline Palaemonetes spp. (L) & 20.1 & 0.14 & 1.53 & $\mathrm{~S}$ & $2.92(1.33-9.17)$ & $0.67(0.58-1.33)$ \\
\hline Amphipods & 2.1 & 0.01 & 0.86 & $\mathrm{~S}$ & $3.33(2.17-9.33)$ & $1.08(0.33-2.17)$ \\
\hline Mysids & 7.5 & 0.05 & 0.30 & $S$ & $3.58(2.33-6.17)$ & $1.17(0.33-1.92)$ \\
\hline Hydromedusae & 10.6 & 0.07 & 0 & $S$ & $4.50(3.67-5.42)$ & $3.58(2.33-6.17)$ \\
\hline Callianassa spp. (L) & 18.1 & 0.13 & 2.18 & S & $4.50(3.67-5.42)$ & $1.17(1.00-1.25)$ \\
\hline Chaetognaths & 118.0 & 0.87 & 0.03 & S & $5.25(3.25-7.58)$ & $0.33(0.17-0.50)$ \\
\hline Fish (L) & 15.0 & 0.11 & 0.03 & S & $6.83(4.00-20.0)$ & $1.17(0.33-3.42)$ \\
\hline
\end{tabular}


Odds Ratlo (L)

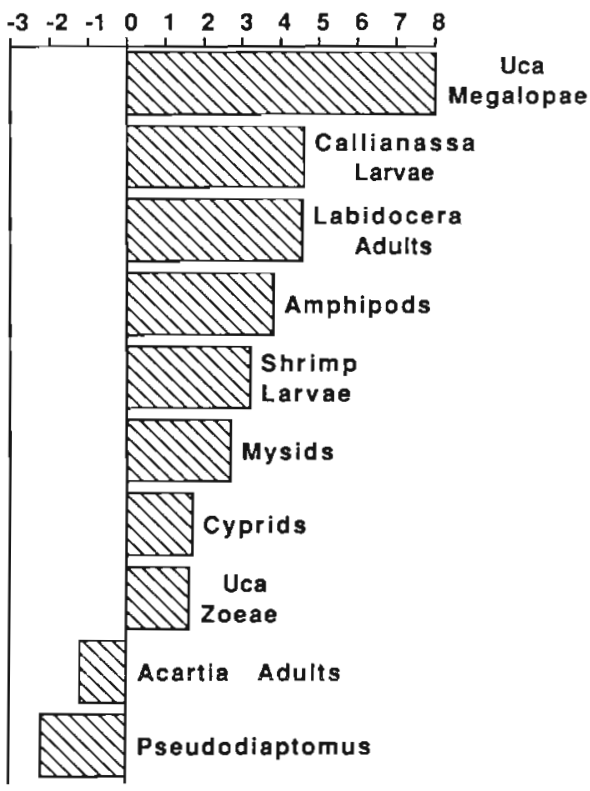

Fig. 3. Anchoa mitchilli. Comparison of average electivity coefficients for major prey taxa consumed by adults over the $40 \mathrm{~h}$ study. Values were determined from stomach contents and simultaneous collections of zooplankton and macrozooplankton. Each value is based on a mean of 16 bihourly samples. $\mathrm{L}=0$ indicates no selection, values $>0$ indicate positive selection for a prey item, values $<0$ indicate that a prey item was not selected. Shrimp larvae include all decapod shrimp taxa except Callianassa spp.

due to increased consumption of Uca megalopae. On these 2 days, the onset of the second high tide coincided with dusk, and, at this time, a sudden shift from smaller to larger secondary prey occurred within a 1 or $2 \mathrm{~h}$ period (Fig. 5). At dusk the first day, the diet, which was dominated by smaller prey (Acartia tonsa,

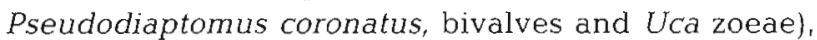
was followed by a rapid switch to the larger Uca megalopae, Labidocera aestiva and Callianassa spp. On the second day, UCa megalopae dominated the diet during both day and night, but a similar switch in secondary prey species took place at dusk.

While the most dramatic shift in the overall feeding pattern over the $40 \mathrm{~h}$ occurred around dusk, consumption of many individual prey showed consistent patterns with tidal and/or diel rhythms (Fig. 6). These consumption patterns remained consistent into the second day for most taxa. In general, the smaller prey items (barnacle cyprids, bivalves, Acartia tonsa and Uca zoeae) comprised more of the diet during the day, especially at low tide, while the larger taxa (Callianassa spp., Labidocera aestiva, mysids, amphipods and Uca megalopae) were eaten in greater numbers at high tide. With the exception of Uca megalopae, the
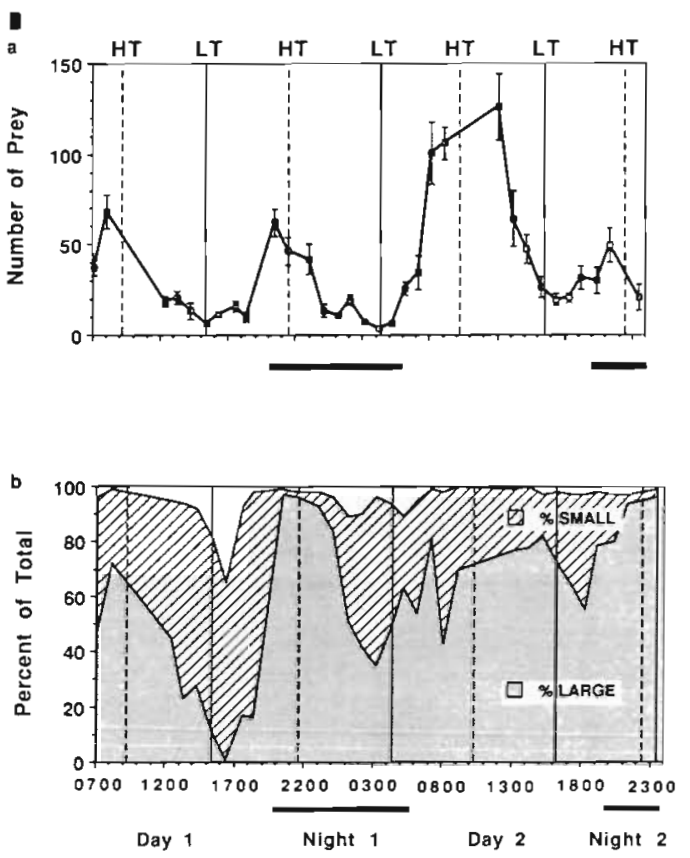

Fig. 4. Anchoa mitchilli. (a) Tidal and diel fluctuations in feeding intensity during the $40 \mathrm{~h}$ period. Values represent mean number of prey iems consumed per fish. Vertical bars indicate one standard error. Bold horizontal lines indicate hours of darkness. HT: high tide, LT: low tide. (b) Percentage of large and small prey items consumed over the $40 \mathrm{~h}$ study. Values for 'large' include UCa megalopae, Labidocera, all decapod shrimps, mysids, and amphipods and those for 'small' include cyprids, molluscs, Uca zoea, Acartia and Pseudodiaptomus (see Table 2). White area represents unidentifiable prey items, minor prey taxa not included in the previous categories, and detritus

Table 3. Anchod mitchilli. Effects of tide and photoperiod on feeding intensity of adults ( 40 to $60 \mathrm{~mm} \mathrm{SL}$ ). Comparisons are based on mean numbers of prey consumed during specific intervals representing different combinations of time of day and tide. Results of 418 stomach analyses were used in these comparisons

(a) Mean number of prey in stomachs

\begin{tabular}{|lcccc|}
\hline Tide & Day & SE & Night & SE \\
\hline High & 57.1 & 5.6 & 25.3 & 4.0 \\
Low & 28.9 & 1.7 & 11.6 & 1.3 \\
\hline
\end{tabular}

(b) ANOVA table of log-transformed data

\begin{tabular}{|lrrrc|}
\hline Source & df & \multicolumn{1}{c}{ SS } & F & p \\
\hline Tidal height & 1 & 15.83 & 78.52 & 0.0001 \\
Day/Night & 1 & 12.16 & 60.31 & 0.0001 \\
Interaction & 1 & 0.11 & 0.54 & 0.4632 \\
$\quad$ Error & 544 & 105.86 & & \\
Total & 547 & 131.45 & & \\
\hline
\end{tabular}



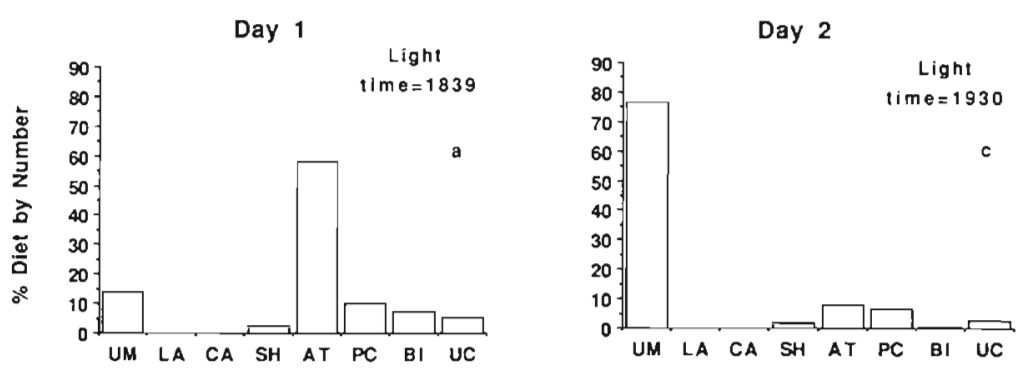

Fig. 5. Relative proportions of large prey (UM, Uca megalopae; LA, Labidocera aestiva; CA, Callianassa spp.; $\mathrm{SH}$, all decapod shrimp except Callianassa) and small prey (AT, Acartia tonsa;

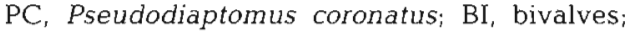
UZ, Uca zoeae) consumed by fishes collected just prior to and just after dusk on both days (see Table 2). Fish sample size and number of prey items in stomachs: (a) 4,79; (b) 18,1237 ; (c) 10 , 313; (d) 10,540
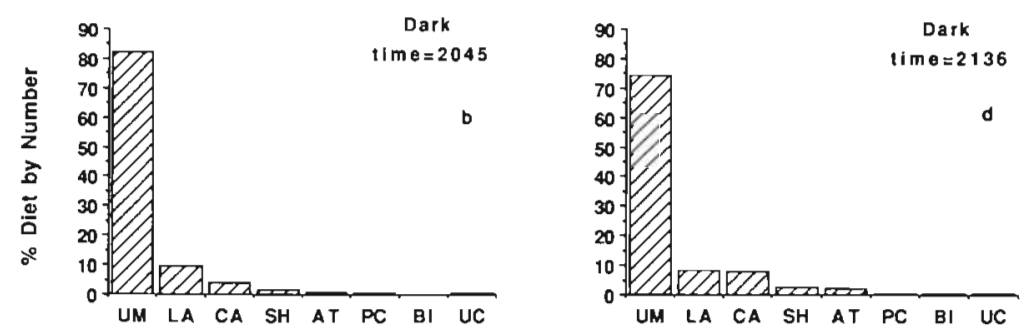

maximum ingestion of larger prey taxa was at night. Thus, although $U_{c a}$ megalopae dominated the diet throughout the study, notable shifts in the relative composition of the secondary prey occurred over the $40 \mathrm{~h}$ period.

Adult bay anchovy consumption patterns closely followed the changing availability of some prey taxa during the $40 \mathrm{~h}$ period (Fig. 7). Most prey with high selection coefficients were incorporated into the diet when their abundance peaked. Consumption of most large prey like Labidocera aestiva. Callianassa, mysids, amphipods, and Palaemonetes shrimp changed coincidentally with nocturnal pulses of these prey items in the water column (e.g. Figs. 7a, b). Smaller prey like bivalves (Fig. 7c) and Acartia tonsa (Fig. 7d) were consumed in higher numbers when large prey were least abundant. Although patterns of numbers of $A$. tonsa and UCa zoeae eaten and collected corresponded well during most of the $40 \mathrm{~h}$ period, patterns for bivalves did not (Figs. $7 c$, d, e). The extremely rapid responses of the fishes to the sudden availability of $A$. tonsa and $U c a$ zoeae on the second day and to $L$. aestiva and, especially, Callianassa on both nights illustrate a strong relationship between prey abundances and fish feeding behavior. Uca megalopae, which were most abundant around high tide, were consumed in large numbers at that time, but proportionately high numbers of megalopae were found in fish stomachs even when prey densities were relatively low (Fig. 7f).

\section{DISCUSSION}

Flexibility in feeding habits is an important adaptation in habitats where fluctuations in the types and amounts of food available are common. Most previous comparisons of fish feeding patterns with simultaneous estimates of prey availability in the field have emphasized the plasticity of the interaction between planktivores and their zooplanktonic prey (Schmitt 1986). Eggers (1978), for example, found that juvenile sockeye salmon Oncorhynchus nerka in Lake Washington (Washington, USA) had high, but quite flexible, preferences for a variety of large and easily caught prey which varied according to their seasonal availability. Only when the preferred prey items were rare or absent were smaller or more elusive prey consumed. A similar pattern of dietary flexibility in response to shifts in prey availability was elucidated for the bay anchovy Anchoa mitchilli in this study in the North Inlet Estuary. This previously unreported ability to alter feeding habits virtually instantaneously is obviously advantageous to fishes inhabiting environments as dynamic as the water column of a tidal estuary.

The speed and extent to which Anchoa mitchilli switched between large and small prey during the $40 \mathrm{~h}$ period may have resulted from a change in feeding behavior. Some planktivores, like the estuarine round herring Gilchristella aestuaris (Talbot \& Baird 1985), alewife herring Alosa pseudoharengus (Janssen 1976 , Crowder \& Binkowski 1983), Pacific mackerel Scomber japonicus (O'Connell \& Zweifel 1972), and northern anchovy Engraulis mordax (Leong \& O'Connell 1969, O'Connell 1972), can shift from particulate feeding on larger prey to filter feeding on smaller particles. Crowder (1985) showed that these switches in foraging mode could be predicted in terms of optimal foraging at different densities of large and small prey. Whether the sudden switch between large and small prey by adult A. mitchilli involves switches between particulate and filter-feeding remains unknown, but filter-feeding in this species has not been observed. Houde and co- 


\section{Cyprids}

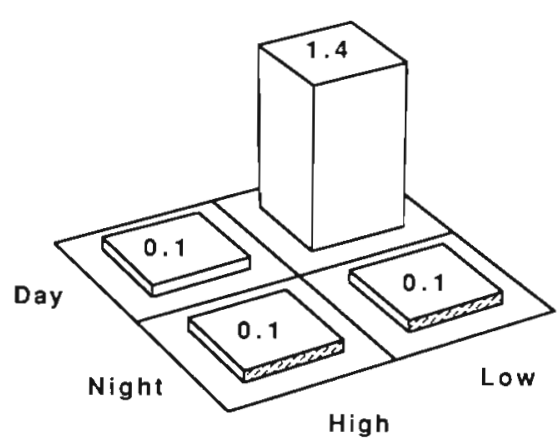

Tide=

Photoperiod $=0.0002^{*}$

interaction $=0.0002$ *
Bivalves

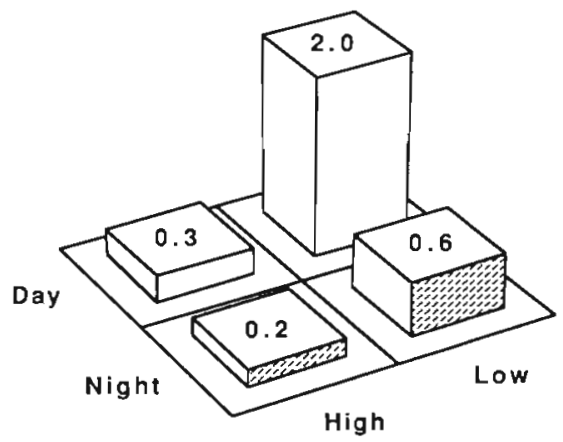

Tide=

$0.0010^{*}$

Photoperiod $=0.0396^{*}$

Interaction $=0.1829$
Acartia tonsa

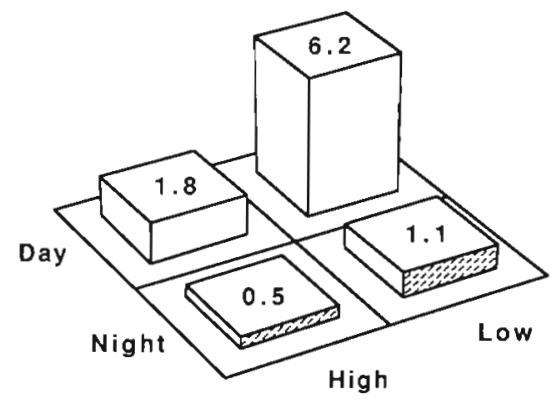

Tíde $=\quad 0.0117^{\star}$

Photoperiod $=0.0003^{*}$ Interaction $=0.1837$
Uca Zoeae

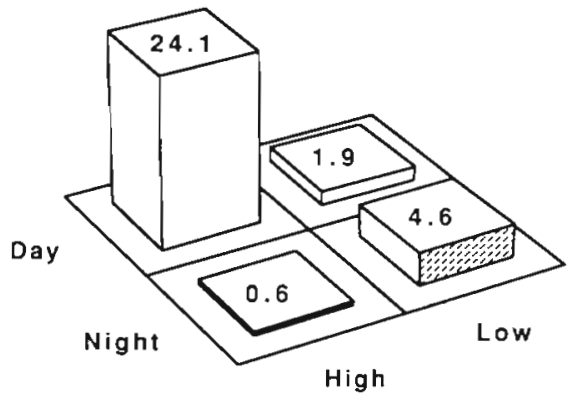

Tide $=$

0.1920

Photoperiod $=0.0047^{*}$

Interaction $=0.0001^{*}$
Callianassa

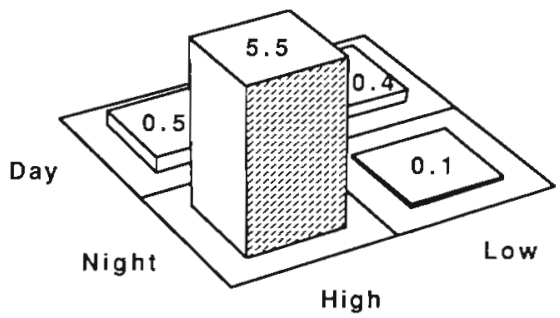

Tide=

$0.0001^{*}$

Photoperiod $=0.0002$ *

Interaction $=0.0001^{\circ}$
Labidocera

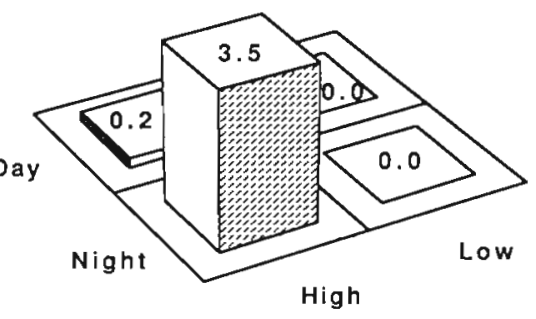

$\begin{array}{lr}\text { Tide }= & 0.0001^{*} \\ \text { Photoperiod }=0.0001^{*} & 0.0001^{*}\end{array}$

\section{Mysids}

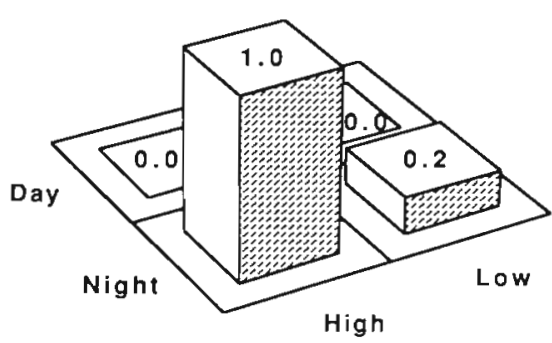

Amphipods

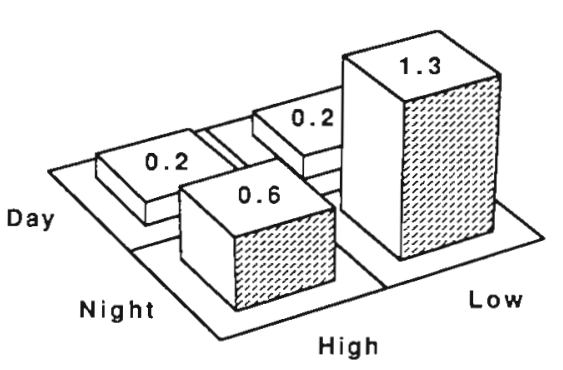

Tide=

0.2998

Photoperiod $=0.0167^{*}$

Interaction $=0.1872$
Uca Megalopae

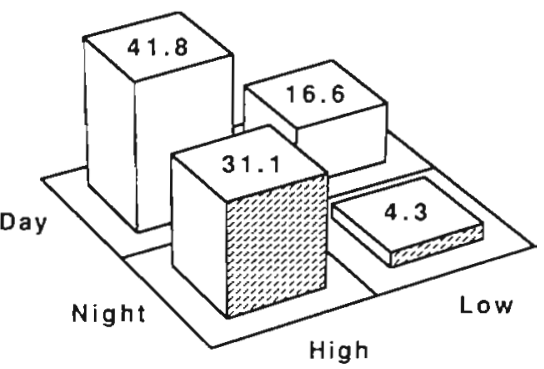

$\begin{array}{ll}\text { Tide }= & 0.0006^{*} \\ \text { Photoperiod }= & 0.1265 \\ \text { Interaction }= & 0.5920\end{array}$

Fig. 6. Anchoa mitchilli. Block diagrams comparing mean numbers of prey taxa consumed by adults during various combinations of tide and time of day. Numbers on top of each block for each taxon indicate a mean value for each time/tide interval. Block heights cannot be compared among taxa. Probabilities resulting from ANOVA's conducted on each prey category are shown; 'significant terms $(\mathrm{p}<0.05)$. Numbers of samples used for each combination of tide and photoperiod: high tide/day ( $\mathrm{n}=6)$, high tide/night $(n=7)$, low tide/day $(n=7)$, low tide/night $(n=4)$ 

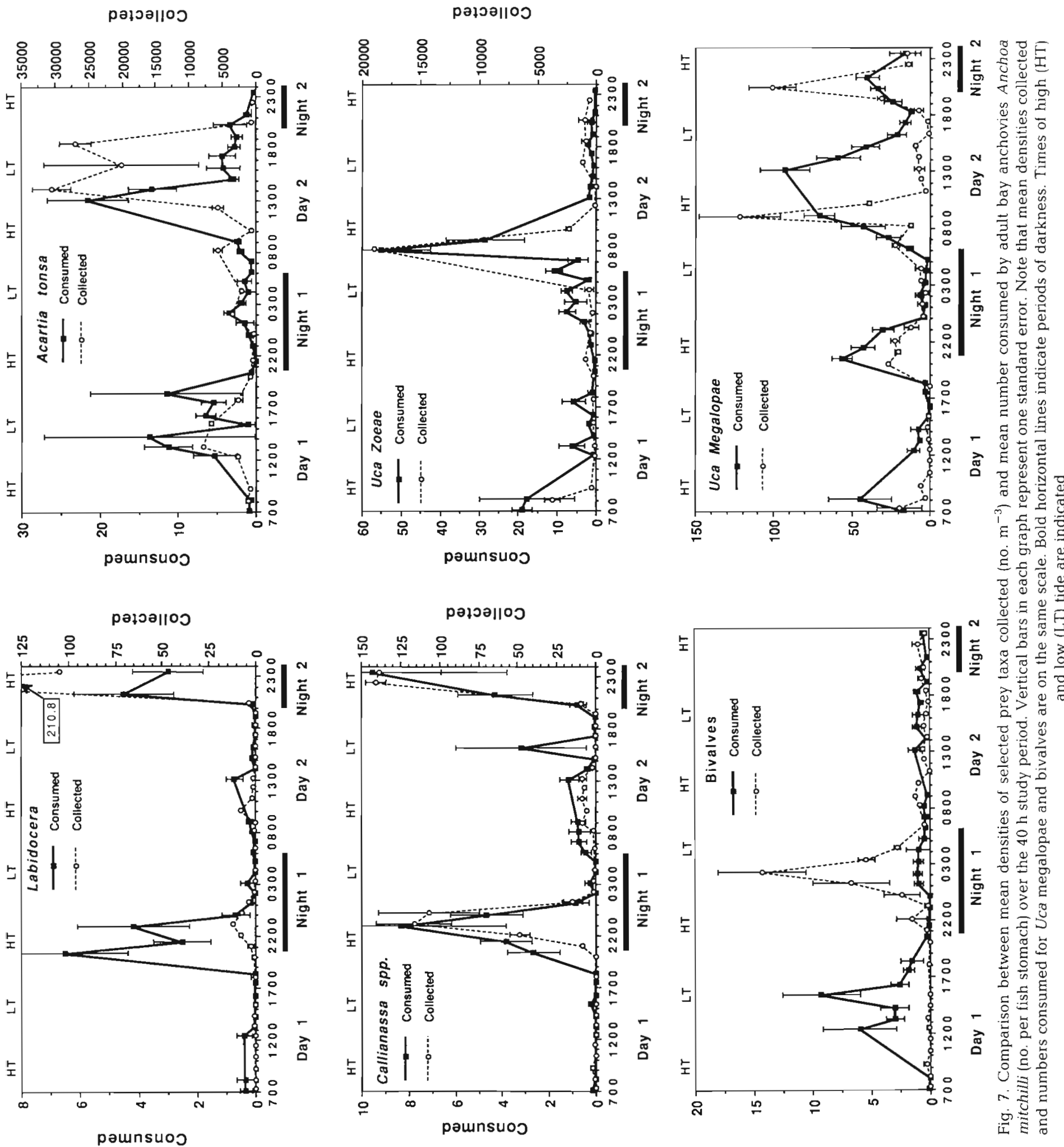
workers clearly established that larval bay anchovies up to $20 \mathrm{~mm}$ are exclusively particulate feeders (Detwyler \& Houde 1970, Houde 1977, 1978, Houde \& Schekter 1980), but difficulties in maintaining larger specimens in the laboratory have thwarted definitive feeding experiments on adults (Fulton 1984, pers. obs.). Switches in feeding behavior need not involve a shift to filter feeding. These fish could form a specific search image (Tinbergen 1960. Beukema 1968) for different types or sizes of prey that accentuates the size selection process. Evidence which strongly supports the idea of feeding according to a specific search pattern occurred on Day 2 when anchovies continued to feed almost exclusively on $U c a$ megalopae which were present at densities of less than $10 \mathrm{~m}^{-3}$, even though Acartia tonsa was present at peak abundances of nearly $30000 \mathrm{~m}^{-3}$.

Analysis of stomach contents of adult Anchoa mitchilli indicated a general preference for larger prey within the range of sizes consumed. Size-selective predation as observed here is commonplace among planktivores (Eggers 1982, Lazzaro 1987). Most models of size-selective feeding by planktivores assume that the fish use visual means to target individual prey (Confer et al. 1978). This might seem unlikely for a fish feeding below the surface in a murky salt marsh habitat, but the ability of fish to feed effectively and often selectively at extremely low light levels or under conditions of high turbidity has been documented in the laboratory (Jones 1956, Hunter 1968, Gardner 1981, Mills et al. 1984). Models based on apparent size (O'Brien et al. 1976) or on relative size of prey (Werner \& Hall 1974, Confer \& Blades 1975) predict that fish will automatically select larger prey without active evaluation or choice by the fish. Selection in favor of larger prey may be more pronounced under conditions of decreased visibility (Moore \& Moore 1976, Wright \& O'Brien 1984). Even so, it seems unlikely that the size selectivity observed here can be attributed to visual phenomena alone. The ingestion of such common small prey as Acartia tonsa was often well below that expected from random encounter. In fact, at times they were so dense $1>20000$ $\mathrm{m}^{-3}$ ) that their presence at fewer than 3 copepods per fish (Fig. 7) might be due to incidental ingestion (Wright \& O'Brien 1984)

Anchoa mitchilli selected prey by type or species even when feeding on prey of similar size. Among smaller prey, crab zoeae and cyprids were favored over the copepods Pseudodiaptomus coronatus and Acartia tonsa. Such preferences can be a function of differential visibility due to pigmentation (Zaret \& Kerfoot 1975), contrast (Lythgoe 1968, Eggers 1977), or movement (Brooks 1968, Confer \& Blades 1975, Vinyard 1980, Zaret 1980, O'Brien 1987). It can also result from differential escape responses of the prey (Drenner et al. 1978, Kerfoot et al. 1980). Copepods have well- documented erratic escape behaviors that make capture more difficult (Confer \& Blades 1975, Shuvayev 1978, Govoni et al. 1986) while cyprids and crab zoea may be weaker swimmers or easier targets. Although the spines and armaments of freshwater cladocerans (O'Brien et al. 1979) and some estuarine crab zoeae (Morgan 1989) have been touted as effective deterrents to small predaceous fishes, such features did not discourage adult $A$. mitchilli from consuming large quantities of spined crustacean larvae (e.g. Callianassa zoeae). Some fish can recognize different prey and actively select them based on anticipated success from recent experiences (Vinyard 1980, 1982, Hansen \& Wahl 1981, Magnhagen 1985), but laboratory observations are required to determine whether the selectivity exhibited by $A$. mitchilli results from prey evasion or from decisions not to attack.

While most studies have emphasized the role of vision in feeding selectivity, non-visual cues may be employed by Anchoa mitchilli to locate, identify, and select prey both at night and under the low light conditions typical of estuarine water columns. Govoni et al. (1986) speculated that larval spot Leiostomus xanthurus and croaker Micropogonias undulatus feed at night using non-visual cues. Ohman (1988) suggested that different types of prey motion including acceleration and interspecific differences in appendage movement produce tactile and hydrodynamic signals important for non-visual predators. Recently, Gill (1987) obtained well-defined specific impedance pneumograph recordings from marine copepods, and Kirk (1985) found that swimming cladocerans and copepods each produced distinctive flow patterns.

Within the size range of prey preferred by adult bay anchovies, some abundant macrozooplankton (hydromedusae, chaetognaths, fish larvae, and pinnotherid crabs) were seldom ingested. The absence of these taxa could be related to the escape ability of the prey alone or to the decision not to pursue them. Of these 4 macrozooplankton types, only fish larvae have been reported as important food for bay anchovies, and those reports are from specific habitats: brackish Lake Pontchartrain, Louisiana, USA (Darnell 1958) and hypersaline canals in Florida, USA (Kinch 1979). Why adult bay anchovies avoided larval fishes as prey items is unknown, but this behavior had a selective advantage for the species since the most common larval fishes in the water column were Anchoa mitchilli. Both. larval fish and chaetognaths appear to be more motile than other zooplankters and, thus, may be ignored in favor of less active prey present at lower densities (Abrams 1987). Low caloric yield plus the threat of nematocysts may discourage feeding on hydromedusae. In contrast, juvenile pinnotherids with a body size intermediate between Uca megalopae and zoeae 
would seem to be attractive prey of reasonable size and low mobility. However, no pinnotherids were found in the 630 A. mitchilli stomachs examined. Recent observations suggest that the free-living stages of Pinnotheres ostreum may have potent chemical rather than physical defenses which result in rejection by fish predators (Luckenbach \& Orth in press). Checkley (1982) noted that certain categories of prey were detected, investigated and then rejected by larval herring Clupea harengus, and it is likely that some aspects of learning, memory and cognition (Magnhagen 1985. Marcotte \& Browman 1986) are important in the selection and rejection of prey by $A$. mitchilli.

Feeding patterns of Anchoa mitchilli are of both ecological and economic interest due to its wide geographical distribution and abundance (Gunter 1938, de Sylva et al. 1962, Kjelson et al. 1974, Allen et al. 1978, Livingston 1982) and because of its role as a direct trophic link to larger food and game fish in inshore waters (de Sylva et al. 1962, Overstreet \& Heard 1982). Previous dietary studies on daytime feeding (Darnell 1958, Sheridan 1978, Kinch 1979, Sheridan \& Livingston 1979, Livingston 1982, Din \& Gunter 1986, Smith et al. 1984) firmly established bay anchovies as zooplanktivores which provide a critical and direct link between copepod productivity and pelagic food webs. Other studies have shown that although adult $A$. mitchilli (above $40 \mathrm{~mm}$ ) consumed large prey items, copepods were the dominant prey. We also found that adult $A$. mitchilli ( 40 to $59 \mathrm{~mm}$ ) could consume a large number of copepods and other smaller zooplankters, especially during the day, but a greater utilization of larger prey, notably UCa megalopae, was observed during both day and night. Furthermore, extensive nocturnal sampling revealed that not only do these fish feed after dark, but they consume an entirely different array of larger prey available only at night (in addition to Uca megalopae). Thus, adult $A$. mitchilli also serve as a connection to the marsh-based benthic food web through extensive consumption of larval or juvenile decapod crustaceans (e.g. Uca, Callianassa, Palaemonetes) and upwardly mobile peracarid crustaceans (e.g. mysids and amphipods) - all common residents of temperate estuarine ecosystems.

In the tropics, there is a similar nocturnal increase in macrozooplankton (Emery 1968, Aldredge \& King 1977), and a separate assemblage of strictly nocturnal fish emerge at dusk to feed on them while the diurnal water column foragers retire for the night (see Hobson $1965,1972,1974)$. Such specialization is not found in the temperate inshore planktivores. Considerable feeding flexibility by Anchoa mitchilli allows it to utilize the larger nocturnal prey as well as the smaller diurnal zooplankton. DeLancey (1987), Christy (1982), and Epifanio et al. (1984) suggested that the appearance of these large prey in the water column at night is timed to reduce their vulnerability to predation. Nocturnal emergence or pulsed releases of decapod larvae may afford them some protection, but adult bay anchovies still selectively fed on these large prey items regardless of the time of day.

Although the high abundance, broad distribution, and planktivorous feeding of Anchod mitchilli are widely recognized (Hildebrand \& Shroeder 1928, Gunter 1945, Leak \& Houde 1987, Ogburn et al. 1988, Baird \& Ulanowicz 1989), its impact on estuarine zooplankton populations is difficult to assess. Since adult bay anchovy feeding appears to be continuous and selective, we hypothesize that they play a significant role in regulating zooplankton community structure. Such 'top-down' control of zooplankton by fishes has been documented in many freshwater systems (Lazzaro 1987), but results from studies in marine environments have been less conclusive, probably because of the open-ended character of such systems. Davis (1984) and Feigenbaum \& Kelley (1984) supplied evidence for control by invertebrate predators, but Peterson \& Ausubel (1984) felt that natural copepod populations were unaffected by selectively feeding Atlantic mackerel Scomber scombrus larvae in Long Island Sound (USA). Local reductions in zooplankton densities in the field have been attributed to planktivorous fish associated with temperate reefs (Bray 1981, Kingsford \& MacDiarmid 1988), and Cushing (1983) and Bollens (1988) provided calculations that suggest that under appropriate conditions planktivorous marine fish should have a considerable impact on their prey. Enclosure experiments using natural densities of fish and zooplankton support this hypothesis (Horsted et al. 1988).

A definitive assessment of the role of adult Anchoa mitchilli in zooplankton population dynamics and community structure depends on accurate estimates of fish densities and daily rations as well as on further information on the diets of other life stages of this dominant planktivore. Fulton (1984) suggested that size selective predation by $A$. mitchilli altered the seasonal succession of estuarine copepods at Beaufort, North Carolina by removing Acartia tonsa and leaving smaller species. The present study on adult bay anchovies indicates that the largest members of this predator population may have an impact on the abundance of other zooplankters including the developmental stages of common estuarine crabs and shrimps.

Acknowledgements. We are grateful to the many staff members and students of the Baruch Institute who assisted in the collection and processing of the field measurements and samples. Special thanks go to D. L. Barker, who analyzed all $153 \mu \mathrm{m}$ zooplankton, and K. Green and J. Wessel, who analyzed the macrozooplankton and epibenthic sled samples. W. 
K. Michener provided much appreciated help with data management and summary statistics. This study was supported by the National Science Foundation grants, DEB-8012165 and BSR-8514326, to the Belle W. Baruch Institute of the University of South Carolina for the Long-Term Ecological Research Program (F. J. Vernberg, Project Director)

\section{LITERATURE CITED}

Abrams, P. (1987). Indirect interactions between species that share a predator: varieties of indirect effects. In: Kerfoot, W C., Sih, A. (eds.) Predation: direct and indirect impacts on aquatic communities. University Press of New England, Hanover, p. 38-54

Alldredge, A. L., King, J. M. (1977). Distribution, abundance, and substrate preferences of demersal reef zooplankton at Lizard Island Lagoon, Great Barrier Reef. Mar. Biol. 41: $317-333$

Allen, D. M. Clymer, J. P., Herman, S. S. (1978). The fishes of the Hereford Inlet Estuary, Southern New Jersey. Department of Biology, Lehigh University, Bethlehem, Pennsylvania

Baird, D., Ulanowicz, R. E. (1989). The seasonal dynamics of the Chesapeake Bay Ecosystern. Ecol. Monogr. 59: 329-364

Beukema, J. J. (1968). Predation by the three-spined stickleback (Gasterosteus aculeatus): the influence of hunger and experience. Behaviour 31 1-126

Bollings, S. M. (1988). A model of the predatory impact of larval marine fish on the population dynamics of their zooplankton prey. J. Plankton, Res. 10: 887-906

Bray, R. N. (1981). Influence of water currents and zooplankton densities on daily foraging movements of blacksmith, Chromis punctipinnis, a planktivorous fish. Fish. Bull. U. S. 78: 829-841

Brooks, J. L. (1968). The effects of prey size selection by lake planktivores. Syst. Zool. 17: 273-291.

Brooks, J. L., Dodson, S. I. (1965). Predation, body size, and composition of plankton. Science 150: 28-35

Checkley, D. M., Jr. (1982). Selective feeding by Atlantic herring (Clupea harengus) larvae on zooplankton in natural assemblages. Mar. Ecol. Prog. Ser. 9: 245-253

Christy, J. (1982). Adaptive significance of semilunar cycles of larval release in fiddler crabs (genus Uca): test of an hypothesis. Biol. Bull. mar. biol. Lab., Woods Hole 163: 251-263

Christy, J. H., Stancyk, S. (1982). Timing of larval production and flux of invertebrate larvae in a well-mixed estuary. In: Kennedy, V S. (ed.) Estuarine comparisons. Academic Press, New York, p. 489-503

Confer, J. L., Blades, P. I. (1975). Omnivorous zooplankton and planktivorous fish. Limnol. Oceanogr. 20: 571-579

Confer, J. L., Howick, G. L., Corzette, M. H., Kramer, S. L., Fitzgibbon, S., Landesberg, R. (1978). Visual predation by planktivores. Oikos 31: 27-37

Crowder, L. B. (1985). Optimal foraging and feeding mode shifts in fishes. Environ. Biol. Fish. 12: 57-62

Crowder, L. B., Binkowski, F. P. (1983). Foraging behaviors and the interactions of alewife, Alosa pseudoharengus, and bloater, Coregonus hovi. Environ. Biol. Fish. 8 $105-1.13$

Cushing, D. H. (1983). Are fish larvae too dilute to affect the density of their food organisms? J. Plankton Res. 5 $847-854$

Dame, R. T., Chrzanowski, K., Bildstein, K., Kjerfve, B. McKeller, H., Nelson, D., Spurrier, J., Stancyk, S., Steven- son, H., Vernberg, J., Zingmark, R. (1986). The outwelling hypothesis in North Inlet, South Carolina. Mar. Ecol. Prog. Ser. 33: 217-229

Darnell, R. M. (1958). Food habits of fishes and larger invertebrates of Lake Pontchartrain, Louisiana, an estuarine community. Publs Inst. mar. Sci. Univ. (Tex.) 5: $353-416$

Davis, C. S. (1984). Predatory control of copepod seasonal cycles on Georges Bank. Mar. Biol. 82: 31-40

de Lafontaine, Y., Sinclair, M., El-Sabh, M. I., Lassus, C., Fournier, R. (1984). Temporal occurrence of ichthyoplankton in relation to hydrographic and biological variables at a fixed station in the St. Lawrence Estuary. Estuar. coast. mar. Sci. 18: 177-190

de Sylva, D. P., Kalber, F. A., Jr, Shuster, C. N., Jr (1962) Fishes and ecological conditions in the shore zone of the Delaware River Estuary, with notes on other species collected in deeper water. Information publ. no. 5, Univ. of Delaware Marine Laboratories, Newark, Delaware, $p$. $1-164$

DeLancey, L. B. (1987). The summer zooplankton of the surf zone at Folly Beach, South Carolina. J. coastal Res. 3: 211-217

Detwyler, R. Houde, E. D. (1970). Food selection by laboratory-reared larvae of the scaled sardine Harengula pensacolae (Pices, Engraulidae). Mar. Biol. 7: $214-222$

Din, Z. B., Gunter, G. (1986). The food and feeding habits of the common bay anchovy, Anchoa mitchilli. Pertanika 9 (1): $99-108$

Drenner, R. W., Strickler, J. R., O'Brien, W. J. (1978). Capture probabilities: the role of zooplankter escape in selective feeding of planktivorous fish. J. Fish. Res. Bd Can. 35: $1370-1373$

Eggers, D. M. (1977). The nature of prey selection by planktivorous fish. Ecology 58: 46-59

Eggers, D. M. (1978). Limnetic feeding behavior of juvenile sockeye salmon in Lake Washington and predator avoidance. Limnol. Oceanogr. 23: 1114-1125

Eggers, D. M. (1982). Planktivore preference by prey size. Ecology 63: 381-390

Emery, A. R. (1968). Preliminary observations on coral reef plankton. Limnol. Oceanogr 13: 293-303

Epifanio, C. E., Valenti, C. C., Pembroke, A. E. (1984). Dispersal and recruitment of blue crab larvae in Delaware Bay. Estuar. coast. Shelf Sci. 18: 1-12

Feigenbaum, D., Kelley, K. (1984). Changes in the lower Chesapeake Bay food chain in presence of the sea nettle Chrysaora quinquecirrha (Scyphomedusa). Mar Ecol. Prog. Ser. 19: 39-47

Fleiss, J. L. (1973). Statistical methods for rates and proportions. John Wiley and Sons, New York

Fulton, R. S. III (1984). Predation, production and the organization of an estuarine copepod community. J. Plankton Res. 6: 399-41.5

Gabriel, W. L. (1979). Statistics of selection. In: Lipovsky, S. J., Simenstad, C. A. (eds.) Gutshop 78: fish lood habits studies. Proc. 2nd Pacific Northwest technical workshop. Washington Sea Grant, Seattle, p. 62-66

Gardner, M. B. (1981). Mechanisms of size selectivity by planktivorous fish: a test of hypotheses. Ecology 62: $571-578$

Gill, C. W. (1987). Recording the beat patterns of the second antennae of calanoid copepods, with a micro-impedance technique. Hydrobiologia 148: 73-78

Govoni, J. J., Ortner, P. B., Faiza, Al-Y., Hill, L. C. (1986). Selective feeding of spot, Leiostomus xanthurus, and 
Atlantic croaker, Micropogonias undulatus, larvae in the Gulf of Mexico. Mar. Ecol. Prog. Ser 28: 175-183

Gunter, G. (1938). Seasonal abundance and distribution of certain estuarine and marine fishes in Louisiana, with particular reference to life histories. Ecol. Monogr 8: 313-346

Gunter, G. (1945). Studies on marine fishes of Texas. Publs Inst. mar. Sci. Univ. Tex. 1 (1): 1-190

Hansen, M. J., Wahl, D. H. (1981). Selection of small Daphnia pulex by yellow perch fry in Oneida Lake, New York. Trans. Am. Fish. Soc. 100: 64-71

Hildebrand, S. F., Shroeder, W. C. (1928). Fishes of Chesapeake Bay. Bull U. S. Bur. Fish. XLIII, p. 1-388

Hobson, E. S. (1965). Diurnal-nocturnal activity of some inshore fishes in the Gulf of California. Copeia 1965: 291-302

Hobson, E. S. (1972). Activity of Hawaiian reef fishes during the evening and morning transition between daylight and darkness. Fish. Bull. U. S. 70: 715-740

Hobson, E. S. (1974). Feeding relationships of teleostean fishes on coral reefs in Kona, Hawaii. Fish. Bull. U. S. 72 : 915-1031

Horsted, S. J., Nielsen, T G., Riemann, Pock-Steen, J., Bjornsen, P. K. (1988). Regulation of zooplankton by suspensionfeeding bivalves and fish in estuarine enclosures. Mar Ecol. Prog. Ser. 48: 217-224

Houde, E. D. (1977). Food concentration and stocking density effects of survival and growth of laboratory reared larvae of the bay anchovy, Anchoa mitchilli and lined sole, Achirus lineatus. Mar. Biol. 43: 333-342

Houde, E. D. (1978). Critical food concentrations for larvae of three species of subtropical marine fishes. Bull. mar. Sci. 28: 395-411

Houde, E. D., Schekter, R. C. (1980). Feeding by marine fish larvae. Developmental and functional responses. Environ. Biol. Fish. 5: 315-334

Hunter, R. (1968). Effects of light on schooling and feeding of jack mackerel, Trachurus symmetricus. J. Fish. Res. Bd Can. 25: 393-497

Jacobs, J. (1974). Quantitative measurement of food selection: a modification of the forage ratio and Ivlev's electivity index. Oecologia (Berl.) 14: 413-417

Janssen, J. (1976). Feeding modes and prey selection in the alewife (Alosa pseudoharengus). J. Fish. Res. Bd Can. 33: $1972-1975$

Jones, F. R. H. (1956). The behavior of minnows in relation to light intensity. J. exp. Biol. 33: 271-281

Jumars, P. A., Self, R. F. L., Nowell, A. R. M. (1982). Mechanisms of particle selection by tentaculate feeders. J. exp. mar. Biol. Ecol. 64: 47-70

Kerfoot, W. C., Kellog, D. L., Strickler, J. R. (1980). Visual observations of live zooplankters: evasion, escape, and chemical defenses. In: Kerfoot, W. C. (ed.) Evolution and ecology of zooplankton communities. The University Press of New England, Hanover, p. 587-593

Kinch, J. C. (1979). Trophic habits of the juvenile fishes within artificial waterways - Macro Island, Florida. Contr. mar. Sci. 22: $77-90$

Kingsford, M. J., MacDiarmid, M. J. (1988). Interrelations between planktivorous reef fish and zooplankton in temperate waters. Mar. Ecol. Prog. Ser. 48: 103-117

Kirk, K. L. (1985). Water flows produced by Daphnia and Diaptomus: implications for prey selection by mechanosensory predators. Limnol. Oceanogr. 30: 679-686

Kitchell, J. F., Carpenter, S. R. (1987). Piscivores, planktivores, fossils, and phorbins. In: Kerfoot, W. C., Sih, A. (eds.)
Predation: direct and indirect impacts on aquatic communities. University Press of New England, Hanover, p. $132-146$

Kjelson, M. A., Johnson, G. N., Garner, R. I., Bell, R. (1974). Estimated biomass for nekton communities and populations in the Newport River estuary and an evaluation of nekton sampling methods. Ann. Rep. NMFS, Beaufort, N. C. Lab., p. 207-237

Kjerfve, B. (1978). Bathymetry as an indicator of net circulation in well-mixed estuaries. Limnol. Oceanogr 23: $816-821$

Kjerfve, B., Proehl, J. A., Schwing, F. B., Seim, H. E., Marozas, M. (1982). Temporal and spatial considerations in measuring estuarine water fluxes. In: Kennedy, V. S. (ed.) Estuarine comparisons. Academic Press, New York, p. $37-51$

Lazzaro, X. (1987). A review of planktivorous fishes: their evolution, feeding behaviors, selectivities, and impacts. Hydrobiologia 146: 97-167

Leak, J. C., Houde, E. D. (1987). Cohort growth and survival of bay anchovy Anchoa mitchilli larvae in Biscayne Bay, Florida. Mar. Ecol. Prog. Ser. 37: 109-122

Lee, W. Y., McAlice, B. J. (1979). Sampling variability of marine zooplankton in a tidal estuary. Estuar, coast. mar Sci. 8: 565-582

Leong, R. J., O'Connell, C. P. (1969). A laboratory study of particulate and filter feeding in the northern anciovy, Engraulis mordax, J. Fish. Res. Bd Can. 26: 557-572

Livingston, R. J. (1982). Trophic organization of fishes in a coastal seagrass system. Mar. Ecol. Prog. Ser. 7: 1-12

Luckenbach, M. W. Orth, R. J. (in press). A chemical defense in Crustacea? J. exp. mar. Biol. Ecol.

Lynch, M. (1979). Predation, competition, and zooplankton community structure: an experimental study. Limnol. Oceanogr 24: 253-272

Lythgoe, J. N. (1968). Visual pigments and visual range under water. Vision Res. 8: 997-1012

Magnhagen, C. (1985). Random prey selection or active choice? An experimental study on prey size selection in three marine fish species. Oikos 45: 206-216

Marcotte, B. M., Browman, H. I. (1986). Foraging behaviour in fishes: perspectives on variance. Environ. Biol. Fist. 16: $25-33$

Mills, E. L., Confer, J. L., Ready, R. C. (1984). Prey selectivity by young yellow perch: the influence of capture success, visual acuity, and prey choice. Trans. Am. Fish. Soc. 133: $579-587$

Moore, J. W., Moore, I. A. (1976). The basis of food selection in flounders, Platyichthys flexus L., in the Severn estuary. J. Fish. Biol. 9: 139-156

Morgan, S. G. (1989). Adaptive significance of spination in estuarine crab zoeae. Ecology 70: 464-482

Murdock, W. W. (1969). Switching in general predators: Experiments on predator specificity and stability of prey populations. Ecol. Monogr. 39: 335-354

O'Brien, W. J. (1979). The predator-prey interaction of planktivorous fish and zooplankton. Am. Sci. 67: 572-581

O'Brien, W. J. (1987). Planktivory by freshwater fish: thrust and parry in the pelagial. In: Kerfoot, W. C., Sih, A. (eds.) Predation: direct and indirect inpacts on aquatic communities. University Press of New England, Hanover, p. 3-16

O'Brien, W. J., Slade, N. A., Vinyard, G. L. (1976). Apparent size at the determinant of prey selection by bluegill sunfish (Lepomis macrochirus). Ecology 57: 1304-1310

O'Brien, W J., Kettle, D., Riessen, H. (1979). Helmets and invisible armor: structure reducing predation from tactile and visual planktivores. Ecology 60: 287-294 
$O^{\prime}$ Connell, C. P. (1972). The interrelation of biting and filtering in the feeding activity of the northern anchovy (Engraulis mordax). J. Fish. Res. Bd. Can 29: 285-293

O'Connell, C. P., Zweifel, J. R. (1972). A läboratory study of particulate and filter feeding of the Pacific mackerel, Scomber japonicus. Fish. Bull. U. S. 70: 973-981

Ohman, D. M. (1988). Behavioral responses of zooplankton to predation. Bull mar. Sci. 43: 530-550

Ogburn, M. V., Allen, D. M., Michener, W K. (1988). Fishes, shrimps, and crabs of the North Inlet Estuary, SC: a fouryear seine and trawl survey. Tech. Rep. Baruch Inst. 88-1. Univ. South Carolina, Columbia, p. 1-299

Overstreet, R. M., Heard, R. W. (1982). Food contents of 6 commercial fishes from Mississippi Sound, USA. Gulf Res. Rep. 7 (2): 137-150

Peterson, W. T., Ausubel, S. J. (1984). Diets and selective feeding by larvae of Atlantic mackerel Scomber scombrus on zooplankton. Mar. Ecol. Prog. Ser. 17: 65-75

SAS Institute (1982). SAS users guide. SAS Institute, Inc., Cary, North Carolina

Schmitt, P. D. (1986). Feeding by larvae of Hypoatherina tropicalis (Pices: Atherinidae) and its relation to prey availability in One Tree Lagoon, Great Barrier Reef, Australia. Environ. Biol. Fish. 16: 79-94

Sheridan, P. F. (1978). Food habits of the bay anchovy, Anchoa mitchilli, in Apalachicola Bay. Northeast Gulf Sci. 2: 126-132

Sheridan, P. F., Livingston, R. J. (1979). Cyclic trophic relations of fishes in an unpolluted, riverdominated estuary in north Florida. In: Livingston, R. J, (ed.) Ecological processes in coastal and marine systems. Plenum Press, New York, p. 143-161

Shuvayev, Y D. (1978). Movements of some planktonic copepods. Hydrobiol. J. 14: 32-36

Smith, S. M., Hoff, J. G., O'Neil, S. P., Weinstein, M. P. (1984). Community and trophic organization of nekton utilizing

This article was submitted to the editor shallow marsh habitats, York River, Virginia. Fish. Bull. U. S. $82: 455-468$

Steedman, H. F. (1976). General and applied data on fixation and preservation of marine zooplankton. In: Steedman, $\mathrm{H}$. F. (ed.) Zooplankton fixation and preservation. Unesco Press, Paris, p. 103-154

Stubblefield, C. L., Lascara, C. M., Veccione, M. (1984), Vertical distribution of zooplankton in a shallow turbid estuary. Contr. mar. Sci. 27: 93-104.

Talbot, M. M. J.-F., Baird, D. (1985). Feeding of the estuarine round herring Gilchristella aestuarius (G \& T) (Stolephoridae). J. exp. mar. Biol. Ecol. 87: 199-214

Tinbergen, L. (1960). The dynamics of insect and bird populations in pine woods. Arch. néerl. Zool. 13: 259-473

Vinyard, G. L. (1980). Differential prey vulnerability and predator selectivity: the effects of evasive prey on sunfish (Lepomis) predation. Can. J. Fish. Aquat. Sci. 38: 2294-2299

Vinyard, G. L. (1982). Variable kinematics of Sacramento perch (Archoplites interruptus) capturing evasive and nonevasive prey. Can. J. Fish. Aquat. Sci. 39: 208-211

Werner, E. E., Hall, D. J. (1974). Optimal foraging and the size selection of prey by the bluegill sunfish (Lepomis macrochirus). Ecology 55: 1042-1052

Wolfe, D. A., Kjerfve, B. (1986). Estuarine variability: an overview. In: Wolfe, D. A. (ed.) Estuarine variability. Academic Press, New York, p. 3-17

Wright, D. J., O'Brien, W. J. (1984), The development and field test of a tactical model of the planktivorous feeding of white crappie (Pomaxias anmularis). Ecol. Monogr. 54: 65-98

Zaret, T. M. (1980). Predation and freshwater communities. Yale University Press, New Haven

Zaret, T. M., Kerfoot, W. C. (1975). Fish predation on Bosmina longirostris: body-size selection versus visibility selection. Ecology 56: 232--237

Manuscript first received: November 15, 1989

Revised version accepted: March 19, 1990 